\title{
KARAKTERISTIK FENOTIPE DAN GENOTIPE IKAN GURAMI, Osphronemus goramy, STRAIN GALUNGGUNG HITAM, GALUNGGUNG PUTIH, DAN HIBRIDANYA
}

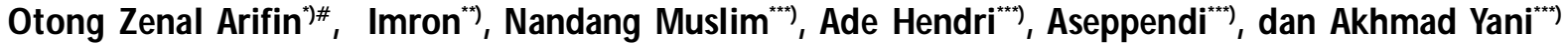 \\ *) Balai Riset Perikanan Budidaya Air Tawar dan Penyuluhan Perikanan \\ **) Balai Riset Pemuliaan Ikan \\ **a Balai Pengembangan Budidaya Ikan Gurami dan Nilem, Singaparna
}

(Naskah diterima: 19 Januari 2017; Revisi final: 2 Maret 2017; Disetujui publikasi: 20 Maret 2017)

\begin{abstract}
ABSTRAK
Persilangan antara dua populasi yang berbeda secara genetik lazimnya menghasilkan kombinasi genetik baru. Penelitian ini dilakukan untuk mengevaluasi karakteristik fenotipe dan genotipe ikan gurami strain Galunggung Hitam, Galunggung Putih, dan Hibridanya. Perkawinan dalam galur (GP X GP dan GH X GH) dan persilangan dua arah antara betina GH dan jantan GP (GH X GP), dan resiprokalnya (GP X GH) telah dilakukan di BPBIGN Singaparna. Fenotipe dianalisis berdasarkan metode truss morfometrik dan meristik, sedangkan karakteristik genotipe diamati menggunakan metode PCR-RAPD. Hasil analisis menunjukkan berdasarkan 21 karakter truss morfometrik, centroid hibrida GH X GP lebih tinggi dari centroid ketiga populasi lainnya pada PC-1 yang dicirikan oleh karakter B3, B4, B5, A3, A4, dan A6, dan bersifat intermediate pada PC-2, PC-3, dan PC-4. Berdasarkan delapan karakter meristik, centroid hibrida GH X GP lebih tinggi dari kedua tetua dan hibrida GP X GH pada PC-1 yang dicirikan oleh karakter SPR dan SDA, lebih rendah dari kedua tetua, tetapi lebih tinggi dari populasi GP X GH pada PC-2, dan lebih rendah dari ketiga populasi lainnya pada PC-3 dan PC-4. Polimorfisme dan heterozigositas pada populasi hibrida GH X GP dan GP X GH lebih tinggi daripada kedua tetuanya GH X GH dan GP X GP. Hibridisasi yang dilakukan meningkatkan variasi genetik yang dapat berguna dalam peningkatan produktivitas budidaya.
\end{abstract}

KATA KUNCl: fenotipe; morfometrik; meristik; genotipe; RAPD; ikan gurami

ABSTRACT: Phenotypeand genotype characteristics of two gouramy (Osphronemus goramy) strains, Galunggung Black and Galunggung White and their hybrids. By: Otong Zenal Arifin, Imron, Nandang Muslim, Ade Hendri, Aseppendi, and Akhmad Yani

\begin{abstract}
Hybridization between two genetically different populations is expected to generate a population carrying new genetic combinations which may be expressed in both phenotypes and genotypes. This study was carried out to explore the phenotype and genotype characteristics of reciprocal hybrids of goramy of Galunggung black (GH) and Galunggung white (GP) with respect to their parental lines. Matings within the same line producing GP X GP and GH X GH, and reciprocal mating producing hybrids GH X GP and GP X GH, were conducted at BPBIGN Singaparna. Samples representing the four populations wereanalyzed for their morphology using truss morphometric and meristic methods, while genotypes were analyzed using PCR-RAPD method. The results showed that based on the 21 morphometric characters, the centroid of hybrid GH X GP was higher than those of the other three populations at PC-1, which was marked by the characters $\mathrm{B} 3, \mathrm{~B} 4, \mathrm{~B} 5, \mathrm{~A} 3, \mathrm{~A} 4$, and $\mathrm{A} 6$, and was intermediate at PC-2, PC-3, and PC-4. Based on the eight meristic characters, the centroid of GH X GP was also higher than those of their parents and hybrids GP X GH at PC-1, which was marked by the characters SPR and SDA, lower than those of their parents but higher than that of hybrid GPX GH at PC-2, and lower than those of the other three populations at PC-3 and PC-4. The genetic diversities in terms of polymorphism and heterozygosity levels in hybrids GH X GP and GP X GH were higher than those found in the pure-line (GH X GH and GPX GP). Hybridization conducted in this study had resulted in the enhancement of genetic variations which could be useful in increasing aquaculture productivity.
\end{abstract}

KEYWORDS: $\quad$ phenotype; morphometric; meristic; genotype; RAPD; gouramy

\footnotetext{
\# Korespondensi: Balai Riset Perikanan Budidaya Air Tawar dan Penyuluhan Perikanan. Jl. Sempur No. 1, Bogor 16154, Indonesia. Tel. + (0251) 8313200

E-mail: zenalarifin@gmail.com
} 


\section{PENDAHULUAN}

Ikan gurami (Osphronemus goramy, Lacepede, 1801) merupakan salah satu jenis ikan air tawar yang memiliki nilai ekonomis tinggi. Di wilayah Jawa Barat, kegiatan pembenihan, dan budidaya telah berlangsung selama puluhan tahun dengan jenis ikan gurami yang banyak dibudidayakan adalah ikan gurami Galunggung (Soang), baik yang berwarna hitam, putih maupun yang berwarna putih dengan bercak hitam pada tubuhnya. Dalam kurun waktu tersebut hampir tidak ada upaya sistematis untuk mengelola kualitas genetiknya. Akibatnya kualitas genetik dari kedua jenis gurami tersebut diduga telah mengalami penurunan sehingga berdampak negatif terhadap performa produksi. Salah satu alternatif untuk mengatasi masalah pertumbuhan yang lambat adalah dengan memperbaiki mutu genetik ikan gurami, perbaikan mutu genetik dapat dilakukan untuk mengatasi kendala kualitas genetik dan pertumbuhan pada ikan gurami (Sularto et al., 2016). Nugroho et al. (2012) mengemukakan bahwa usaha perbaikan genetik untuk mempercepat laju pertumbuhan dan aplikasi teknologi yang tepat guna dalam meningkatkan produksi sangat diperlukan, salah satu cara untuk memperbaiki genetis ikan gurame dengan penerapan persilangan atau hibridisasi.

Hibridisasi adalah perkawinan silang antara dua spesies ikan yang dekat kekerabatannya tetapi mempunyai sifat dan ciri yang berbeda sehingga dapat dihasilkan keturunan dengan sifat dan ciri yang diinginkan. Hibridisasi dapat digunakan untuk menghasilkan benih hibrida yang lebih cepat pertumbuhannya daripada kedua induknya (hybrid vigor). Hibridisasi merupakan salah satu alternatif perbaikan genetis untuk meningkatkan produksi komoditas bernilai ekonomi (Radona \& Nafiqoh, 2014). Selain ditujukan untuk menghasilkan performa yang unggul, hibridisasi juga biasanya disertai dengan munculnya karakteristik fenotipe dan genotipe yang baru.

Pengukuran untuk mendapatkan informasi keragaman genetik dapat didekati melalui evaluasi pada keragaman fenotipe dan genotipe. Studi keragaman genetik berdasarkan karakter fenotipe di antaranya dapat dilakukan dengan mengukur morfologi, baik pada karakter morfometrik maupun meristik. Karakter morfometrik telah lama digunakan untuk mengukur jarak dan hubungan kekerabatan dalam mengategorikan variasi dalam taksonomi seperti telah dilakukan Aryanto \& Imron (2008) pada ikan mas (Cyprinus carpio), Arifin et al. (2015) pada ikan semah (Tor douronensis), Langer et al. (2013) pada golden mahseer (Tor putitora), Setijaningsih et al. (2007) pada ikan gurami dan pada jenis ikan lainnya.
Meristik merupakan ciri yang berkaitan dengan jumlah bagian tertentu dari tubuh ikan, dapat digunakan untuk menggambarkan keterangan-keterangan spesies ikan, atau digunakan untuk identifikasi spesies yang belum diketahui. Ciri yang berkaitan dengan jumlah bagian tertentu dari tubuh ikan, yang meliputi jumlah sirip, perumusan jari-jari sirip, sisik, dan insang (Rahardjo et al., 2010). Studi keragaman genetik berdasarkan karakter genotipe dapat dilakukan di antaranya melalui teknik randomly amplified polymorphisms DNA (RAPD). RAPD merupakan teknik molekuler yang berbasis PCR yang dapat digunakan untuk mendeteksi polimorfisme ruas nukleotida pada DNA dengan memanfaatkan primer tunggal yang memiliki urutan nukleotida acak.

Penelitian ini dilakukan untuk mendeskripsikan keragaman fenotipe dan genotipe pada ikan gurami Galunggung Hitam dan Galunggung Putih dan hasil persilangan dua arah antara kedua strain tersebut. Deskripsi karakter fenotipe dilakukan melalui analisis karakter morfometrik dan meristik, sedangkan analisis karakter genotipe dilakukan melalui analisis RAPD.

\section{BAHAN DAN METODE}

\section{Ikan Uji}

Ikan uji merupakan ikan koleksi Balai Pengembangan Budidaya Ikan Gurame dan Nilem (BPBIGN), Singaparna. Pengujian dilakukan terhadap empat populasi ikan gurami, yaitu populasi gurami Galunggung Hitam (GH X GH), Galunggung Putih (GP $X$ GP), hibrida betina GH dengan jantan GP (GH X GP) dan hibrida dari betina GP dengan jantan GH (GP X $\mathrm{GH}$ ). Setiap persilangan menggunakan sebanyak tiga ekor jantan dan sembilan ekor betina. Tiga puluh ekor ikan ukuran konsumsi (umur 16 bulan, bobot sekitar $800 \mathrm{~g}$ ) dari setiap populasi tersebut diambil sebagai sampel dan diukur morfometrik dan meristiknya.

\section{Pengukuran Karakter Morfometrik dan Meristik}

Analisis dilakukan menggunakan metode "truss morphometric" mengacu pada cara pengukuran Brzesky $\&$ Doyle (1988), meliputi: pengukuran jarak titik-titik tanda yang dibuat pada kerangka tubuh. Sebanyak 30 ekor ikan dari setiap populasi digunakan untuk analisis ini. Ikan difoto menggunakan digital kamera 108PENTX, 16.0 megapixel. Titik karakter ditandai, hasil penandaan dihubungkan dan diukur menggunakan jangka sorong dengan ketelitian 0,01 mm. Deskripsi titik truss tertera pada Tabel 1. Data seluruh karakter dikonversi ke dalam rasio dengan cara membagi masing-masing nilai pengukuran dengan panjang standar. Analisis meristik dilakukan dengan menghitung jumlah jari-jari keras dan lunak pada sirip 
punggung, sirip dada, sirip perut, sirip anal dan sirip ekor, serta jumlah sisik linealateralis (Saanin, 1984). Analisis meristik dilakukan terhadap 30 ekor sampel dari setiap populasi. Deskripsi lengkap karakter meristik disajikan pada Tabel 1.

\section{Karakter Genotipe}

Karakter genotipe dianalisis menggunakan metode PCR-RAPD. Sepuluh ekor ikan untuk masing-masing populasi persilangan dianalisis menggunakan dua primer yaitu OPA-4 (5'-AATCGGGCTG-3') dan OPA-20 (5'-GTTGCGATCC-3'). Pengujian dilakukan di Laboratorium Biologi Molekuler BPPBAT Bogor. DNA

Tabel 1. Deskripsi 21 karakter morfologis morfometrik dan delapan karakter meristik yang dievaluasi untuk analisis variabilitas intraspesifik

Table 1. Evaluated morphological morphometric and meristic characters in the intra specific variability analysis

\begin{tabular}{|c|c|c|}
\hline \multirow{2}{*}{$\begin{array}{l}\text { Ruang truss } \\
\text { Truss area }\end{array}$} & \multirow{2}{*}{$\begin{array}{l}\text { Kode } \\
\text { Code }\end{array}$} & Karakter morfometrik (Morphometric characters) \\
\hline & & Deskripsi jarak (Description of distance) \\
\hline \multirow{6}{*}{$\begin{array}{l}\text { Kepala } \\
\text { Head }\end{array}$} & Al & Ujung operculum bawah-ujung mulut (Bottom tip operculum- mouth tip ) \\
\hline & A2 & Ujung operculum bawah- sirip ventral (Bottom operculum tip- ventral fin ) \\
\hline & $\mathrm{A} 3$ & Ujung operculum bawah-atas mata (Bottom operculum tip- upper eye) \\
\hline & A4 & Ujung mulut-sirip ventral (M outh tip- ventral fin ) \\
\hline & A5 & Ujung mulut-atas mata (M outh tip- upper eye) \\
\hline & A6 & Sirip ventral-atas mata (Ventral fins- upper eye) \\
\hline \multirow{5}{*}{$\begin{array}{l}\text { Tengah } \\
\text { tubuh } \\
\text { Middle } \\
\text { body }\end{array}$} & B1 & Sirip ventral-awal sirip anal (Nentral fins- upper eye) \\
\hline & B3 & Sirip ventral-awal sirip dorsal (Ventral fins- anterior dorsal fins) \\
\hline & B4 & Atas mata- awal sirip anal (Upper eye- anterior anal fins) \\
\hline & B5 & Atas mata- awal sirip dorsal (Upper eye- anterior dorsal fins) \\
\hline & B6 & Awal sirip anal- awal sirip dorsal (Anterior anal fins- anterior dorsal fins) \\
\hline \multirow{5}{*}{$\begin{array}{c}\text { Tubuh } \\
\text { belakang } \\
\text { Rear } \\
\text { body }\end{array}$} & $\mathrm{C} 1$ & Awal sirip anal-akhir sirip anal (Anterior anal fins- posterior anal fins) \\
\hline & C3 & Awal sirip anal- akhir sirip dorsal (Anterior anal fin- posterior dorsal fin ) \\
\hline & C4 & Awal sirip dorsal-akhir sirip anal (Anterior dorsal fins- posterior anal fins) \\
\hline & C5 & Awal sirip dorsal-akhir sirip dorsal (Anterior dorsal fins- posterior dorsal fins) \\
\hline & C6 & Akhir sirip anal- akhir sirip dorsal (Posterior anal fin- posterior dorsal fins) \\
\hline \multirow{5}{*}{$\begin{array}{l}\text { Pangkal } \\
\text { ekor } \\
\text { Caudal } \\
\text { peduncle }\end{array}$} & D1 & Akhir sirip anal-awal sirip ekor bawah (Posterior anal fins- anterior down caudal fins) \\
\hline & D3 & Akhir sirip anal- awal sirip ekor atas (Posterior anal fins- anterior upper caudal fins) \\
\hline & D4 & Akhir sirip dorsal-awal sirip ekor bawah (Posterior dorsal fins- anterior down caudal fins) \\
\hline & D5 & Akhir sirip dorsal- awal sirip ekor atas (Posterior dorsal fins- anterior upper caudal fins) \\
\hline & D6 & Awal sirip ekor bawah-akhir sirip ekor atas (Anterior down caudal fins- posterior upper caudal fins) \\
\hline \multicolumn{3}{|r|}{ Karakter meristik (Meristic characters) } \\
\hline & $\begin{array}{l}\text { Kode } \\
\text { Code }\end{array}$ & Deskripsi (Description) \\
\hline & SPK & Jumlah jari-jari keras sirip punggung (Dorsal fin spiny rays) \\
\hline & SPL & Jumlah jari-jari lunak sirip punggung (Dorsal fin soft rays) \\
\hline & SDA & Jumlah jari-jari sirip dada (Pectoral fin rays) \\
\hline & SPR & Jumlah jari-jari sirip perut (Ventral fin rays) \\
\hline & SAL & Jumlah jari-jari lunak sirip anal (Anal fin soft rays) \\
\hline & SAK & Jumlah jari-jari keras sirip anal (Anal fin spiny rays) \\
\hline & SEK & Jumlah jari-jari sirip ekor (Caudal fin rays) \\
\hline & LL & Jumlah sisik pada garis tepi (Linealateralis) \\
\hline
\end{tabular}


uji yang digunakan berasal dari jaringan sirip dada, dihasilkan dari proses ekstraksi menggunakan Genomic DNA Purification Kit (Fermentas). Komposisi reaksi PCRadalah: DNA $1 \mu \mathrm{L}$; primer $0,5 \mu \mathrm{L}$ konsentrasi 25 nmol (pengenceran 20:80); mastermix PCR (KAPA Robust kk 5701) 6,5 $\mu \mathrm{L}$; akuades $2 \mu \mathrm{L}$; sehingga diperoleh volume total $10 \mu \mathrm{L}$. Selanjutnya tabung mikro dimasukkan dalam thermocycler untuk diamplifikasi, yaitu satu siklus denaturasi awal pada suhu $94^{\circ} \mathrm{C}$ selama dua menit, 34 siklus yang terdiri atas denaturasi pada suhu $94^{\circ} \mathrm{C}$ selama satu menit, annealing $36^{\circ} \mathrm{C}$ selama satu menit, dan elongasi $72^{\circ} \mathrm{C}$ selama dua menit. Elongasi akhir pada suhu $72^{\circ} \mathrm{C}$ selama tujuh menit. Hasil PCR dilihat melalui elektroforesis dalam gel agarose $1,5 \%$

\section{Analisis Data}

Data morfometrik dan meristik dianalisis dengan analisis komponen utama (Principal Component Analysis, PCA). PCA mentransformasi data yang kompleks (multivariable) dan berdimensi besar ke dalam bentuk yang lebih sederhana, dalam bentuk sumbu-sumbu komponen utama yang merupakan ekstraksi dari variabel asal. Kontribusi variabel dan skor individuindividu terhadap sumbu-sumbu utama divisualisasikan dalam bentuk Biplot. Posisi populasi dianalisis secara deskriptif dengan membandingkan nilai tengah multivariate (centroid) pada empat sumbu utama pertama (PC-1-PC4). Analisis PCA dilakukan dengan aplikasi statistik SYSTAT 11.

Nilai heterosis dihitung menggunakan rumus berdasarkan Sheridan (1981):

$$
H=\frac{\frac{(A B+B A)}{2}-\frac{(A A+B B)}{2}}{\frac{(A A+B B)}{2}} \times 100
$$

di mana:

$$
\begin{array}{ll}
\mathrm{H} & =\text { nilai heterosis }(\%) \\
\mathrm{AB}+\mathrm{BA} & =\text { komponen persilangan resiprok } \\
\mathrm{AA} \text { atau } \mathrm{BB} & =\text { komponen true breeding }
\end{array}
$$

Keragaman genetik dianalisis menggunakan program TFPGA (Tools for Population Genetics Analysis) (Nei \& Tajima, 1981). Hubungan kekerabatan antar individu dianalisis menggunakan jarak genetik berdasarkan program UPGMA modifikasi Rogers (1972) dari software TFPGA dari software TFPGA. Polimorfisme genetik diukur dengan rataan heterozigositas $(H)$, jumlah, dan frekuensi alel yang dihitung untuk semua lokus (Miller, 1997).

\section{HASIL DAN BAHASAN}

\section{Analisis Morfometrik}

Seluruh populasi persilangan ikan gurami mempunyai rerata ukuran panjang standar hampir sama, nilai rerata ukuran, dan standar deviasi yang diperoleh untuk masing-masing karakter populasi hasil persilangan dua arah tertera pada Tabel 2 .

Analisis Komponen Utama (PCA) terhadap 21 karakter morfometrik menunjukkan bahwa empat sumbu utama pertama (PC-1, PC-2, PC-3, dan PC-4) secara kumulatif mampu menjelaskan keragaman $62,38 \%$ Sumbu utama PC-1 yang menjelaskan keragaman 25,07\%dicirikan oleh karakter B4, A4, B5, $A 3$, dan B3. Pada sumbu utama $P C-2$ yang menjelaskan keragaman 15,48\% karakter C3, C4, C5, dan D6 memberikan kontribusi yang penting. Pada sumbu PC3 dan PC-4, selain kemampuan menjelaskan keragaman semakin kecil peran dari karakter-karakter penciri pada sumbu-sumbu tersebut tersebut juga semakin lemah yang ditunjukkan oleh nilai-nilai yang lebih kecil dibandingkan dengan yang terdapat pada PC-1 dan PC2 (Gambar 3). Karakter-karakter yang menjadi penciri pada PC-3 adalah D4, D3, dan A5, sedangkan pada PC4 adalah B1 dan D3 (Tabel 3).

Distribusi individu-individu dari keempat populasi pada sumbu utama PC-1 dan PC-2 menunjukkan bahwa populasi hibrida GH X GP berbeda dari ketiga populasi lainnya. Centroid GH X GP bernilai positif dan terletak jauh dari titik tengah sumbu, sementara ketiga populasi lainnya bernilai negatif (Tabel 3 dan Gambar 1). Artinya, pada karakter-karakter yang menjadi penciri pada PC-1, yaitu B4, A4, A6, B5, A3, dan B3, populasi hibrida GH X GP berukuran lebih besar dari ketiga populasi yang lain, dengan perbedaan paling kontras antara GH X GP dan GP X GP. Berdasarkan karakter yang menjadi penciri pada $\mathrm{PC}-2$, populasi tetua saling berjauhan, sedangkan kedua hibrida resiprokalnya berada di antara kedua tetua (Tabel 3 dan Gambar 1). Pola diferensiasi populasi berdasarkan karakter morfometrik juga terlihat pada PC-3 dan PC4. Pada karakter yang menjadi penciri pada PC-3. Hibrida GP X GH berukuran paling kecil dibandingkan dengan tiga populasi lainnya, dengan perbedaan yang paling menonjol ketika dibandingkan dengan populasi tetua GP X GP. Pada PC-4, dua populasi tetua berada pada titik ekstrem yang berlawanan, sedangkan kedua populasi hibrida berada di antarakedua tetuanya (Tabel 3 dan Gambar 2).

Secara umum, alasan utama para pemulia atau pembudidaya melakukan hibridisasi adalah dalam rangka mendapatkan efek heterosis, yaitu performa 
Tabel 2. Nilai rerata ukuran karakter truss pada dua populasi hibrida ikan gurami (GP X GH dan GH X GP) dan dua populasi tetuanya (GP X GP dan GH X GH)

Table 2. The averages of truss-morphometric characters from two populations of hybrid gouramy (GP X GH and GH X GP) and two populations of their parental lines (GP X GP and GH X GH)

\begin{tabular}{ccccc}
\hline \multirow{2}{*}{$\begin{array}{c}\text { Kode karakter } \\
\text { Code of characters }\end{array}$} & \multicolumn{4}{c}{$\begin{array}{c}\text { Nilai rerata X Standar deviasi } \\
\text { Average X Standard deviation } \mathbf{( c m})\end{array}$} \\
\cline { 2 - 5 } & GP X GP & GH X GH & GP X GH & GH X GP \\
\hline PS & $24.30 \pm 2.07$ & $23.90 \pm 2.12$ & $25.60 \pm 2.43$ & $23.70 \pm 2.27$ \\
A1 & $1.83 \pm 0.231$ & $1.76 \pm 0.158$ & $1.80 \pm 0.221$ & $1.78 \pm 0.155$ \\
A2 & $1.92 \pm 0.266$ & $1.78 \pm 0.204$ & $1.75 \pm 0.212$ & $1.64 \pm 0.222$ \\
A3 & $1.90 \pm 0.316$ & $1.79 \pm 0.173$ & $1.82 \pm 0.322$ & $1.76 \pm 0.196$ \\
A4 & $3.60 \pm 0.455$ & $3.58 \pm 0.319$ & $3.50 \pm 0.427$ & $3.29 \pm 0.285$ \\
A5 & $1.02 \pm 0.103$ & $0.96 \pm 0.084$ & $0.95 \pm 0.108$ & $0.99 \pm 0.129$ \\
A6 & $3.43 \pm 0.476$ & $3.27 \pm 0.350$ & $3.30 \pm 0.464$ & $2.99 \pm 0.328$ \\
B1 & $1.02 \pm 0.155$ & $0.95 \pm 0.165$ & $1.04 \pm 0.267$ & $0.99 \pm 0.137$ \\
B3 & $4.30 \pm 0.550$ & $3.96 \pm 0.427$ & $4.02 \pm 0.711$ & $3.63 \pm 0.408$ \\
B4 & $4.28 \pm 0.533$ & $4.00 \pm 0.377$ & $4.08 \pm 0.644$ & $3.82 \pm 0.388$ \\
B5 & $3.79 \pm 0.538$ & $3.57 \pm 0.377$ & $3.59 \pm 0.553$ & $3.17 \pm 0.333$ \\
B6 & $4.37 \pm 0.495$ & $3.94 \pm 0.435$ & $4.00 \pm 0.718$ & $3.69 \pm 0.461$ \\
C1 & $5.02 \pm 0.733$ & $4.31 \pm 0.482$ & $4.70 \pm 0.960$ & $4.30 \pm 0.556$ \\
C3 & $5.23 \pm 0.723$ & $4.70 \pm 0.544$ & $4.84 \pm 0.940$ & $4.44 \pm 0.546$ \\
C4 & $4.98 \pm 0.727$ & $4.27 \pm 0.525$ & $4.56 \pm 0.896$ & $4.27 \pm 0.550$ \\
C5 & $3.71 \pm 0.425$ & $3.18 \pm 0.469$ & $3.42 \pm 0.725$ & $3.22 \pm 0.413$ \\
C6 & $1.80 \pm 0.316$ & $1.66 \pm 0.217$ & $1.62 \pm 0.305$ & $1.51 \pm 0.285$ \\
D1 & $0.59 \pm 0.074$ & $0.52 \pm 0.079$ & $0.51 \pm 0.099$ & $0.36 \pm 0.052$ \\
D3 & $1.71 \pm 0.273$ & $1.53 \pm 0.231$ & $1.53 \pm 0.295$ & $1.25 \pm 0.207$ \\
D4 & $2.07 \pm 0.389$ & $1.71 \pm 0.179$ & $1.82 \pm 0.358$ & $1.63 \pm 0.267$ \\
D5 & $1.21 \pm 0.202$ & $1.14 \pm 0.117$ & $1.26 \pm 0.190$ & $1.01 \pm 0.160$ \\
D6 & $1.64 \pm 0.327$ & $1.41 \pm 0.238$ & $1.41 \pm 0.247$ & $1.23 \pm 0.231$ \\
\hline & & & & \\
\hline & & &
\end{tabular}

hibrida yang lebih unggul daripada tetuanya pada karakter-karakter yang penting untuk budidaya, seperti pertumbuhan dan ketahanan terhadap penyakit. Namun tujuan ini tidak selalu mudah diperoleh. Berbeda dengan metoda seleksi yang bekerja dengan mengeksploitasi keragaman genetik aditif, hibridisasi bekerja dengan mengeskploitasi keragaman genetik dominan. Keragaman genetik aditif merupakan fungsi dari alel-alel, bersifat akumulatif dan diwariskan dari satu generasi ke generasi berikutnya. Keragaman genetik dominan merupakan fungsi dari interaksi/kombinasi alel-alel yang terbentuk pada saat terjadi fertilisasi. Keragaman genetik ini lazim dieksploitasi melalui hibridisasi (Tave, 1999). Efek heterosis diperoleh pada suatu hibrida terjadi ketika kombinasi alel yang terbentuk menghasilkan performa yang lebih baik dari tetuanya. Namun kondisi yang berbeda dari harapan juga sangat banyak terjadi. Performa hibrida dapat sama, berada di antara kedua tetua (intermédiate), atau bahkan lebih buruk dari tetuanya. Dalam penelitian ini, seluruh kombinasi performa hibrida yang meliputi heterosis positif, heterosis negatif, dan intermédiate terjadi.

Fenomena heterosis positif misalnya terlihat pada hibrida GH X GP untuk karakter morfometrik B4, A4, B5, A3, dan B3, dan pada hibrida GP X GH untuk karakter morfometrik D6, C3, C4, dan C5. Fenomena heterosis negatif terlihat pada hibrida GP X GH untuk karakter morfometrik D4, D3, dan A5, sedangkan fenomena performa intermediate terlihat pada hibrida GP X GH untuk karakter morfometrik B1 dan D1. Beragamnya profil fenotipik hasil hibridisasi yang terlihat pada penelitian ini sejalan dan mengonfirmasi teori bahwa hasil hibridisasi tidak dapat diprediksi sebelumnya. Bahkan untuk kombinasi populasi yang menghasikan heterosis positif, besaran tingkat heterosis bervariasi tergantung karakter. 
Tabel 3. Skor 21 karakter morfometrik, ragam, dan centroid empat poulasi pada empat sumbu utama

Table 3. The scores of 21 morphometric characters, variances, and centroids of the four populations on the four main axes

\begin{tabular}{|c|c|c|c|c|}
\hline Karakter (Characters) & PC-1 & PC-2 & PC-3 & PC-4 \\
\hline $\mathrm{A} 1$ & 0.372 & 0.003 & 0.276 & 0.020 \\
\hline $\mathrm{A} 2$ & 0.209 & 0.043 & 0.150 & 0.102 \\
\hline A3 & 0.444 & 0.094 & 0.185 & 0.011 \\
\hline A4 & 0.634 & 0.002 & 0.085 & 0.022 \\
\hline A5 & 0.091 & 0.002 & 0.280 & 0.134 \\
\hline A6 & 0.512 & 0.080 & 0.033 & 0.006 \\
\hline B1 & 0.001 & 0.139 & 0.010 & 0.334 \\
\hline B3 & 0.454 & 0.108 & 0.010 & 0.147 \\
\hline B4 & 0.667 & 0.008 & 0.000 & 0.033 \\
\hline B5 & 0.465 & 0.035 & 0.125 & 0.093 \\
\hline B6 & 0.359 & 0.214 & 0.000 & 0.037 \\
\hline $\mathrm{C} 1$ & 0.341 & 0.288 & 0.021 & 0.196 \\
\hline C3 & 0.052 & 0.634 & 0.002 & 0.041 \\
\hline C4 & 0.145 & 0.591 & 0.014 & 0.007 \\
\hline C5 & 0.139 & 0.434 & 0.049 & 0.080 \\
\hline $\mathrm{C} 6$ & 0.053 & 0.002 & 0.103 & 0.162 \\
\hline D1 & 0.153 & 0.049 & 0.156 & 0.223 \\
\hline D3 & 0.158 & 0.001 & 0.355 & 0.175 \\
\hline D4 & 0.006 & 0.082 & 0.422 & 0.011 \\
\hline D5 & 0.012 & 0.061 & 0.082 & 0.097 \\
\hline D6 & 0.001 & 0.381 & 0.256 & 0.048 \\
\hline $\begin{array}{l}\text { Ragam yang dapat dijelaskan oleh komponen } \\
\text { Variance that can be explained by component }\end{array}$ & 5.266 & 3.250 & 2.615 & 1.979 \\
\hline $\begin{array}{l}\text { Persentase ragam yang dapat dijelaskan oleh komponen } \\
\text { Percentage of variance that can be explained by component }\end{array}$ & 25.074 & 15.478 & 12.45 & 9.426 \\
\hline $\begin{array}{l}\text { Persentase ragam kumulatif } \\
\text { Percentage of cumulative variance }\end{array}$ & 25.074 & 40.553 & 53.003 & 62.429 \\
\hline Centroid POP-GPGP & -1.221 & 0.654 & 1.166 & -0.404 \\
\hline Centroid POP-GHGH & -0.759 & -0.662 & -0.029 & 0.477 \\
\hline Centroid POP-GPGH & -0.210 & -0.070 & -1.444 & -0.138 \\
\hline Centroid POP-GHGP & 2.189 & 0.079 & 0.308 & 0.066 \\
\hline
\end{tabular}

Keterangan: Nilai yang dicetak tebal merupakan karakter yang menjadi penciri pada sumbu utama Note: $\quad$ The values in bold are the identifier characters on the main axis

\section{Analisis Meristik}

Berdasarkan analisis terhadap delapan karakter meristik, empat sumbu utama pertama mampu menjelaskan keragaman $66,85 \%$ SPR dan SDA merupakan karakter penciri pada sumbu PC-1 yang menjelaskan keragaman 26,18\% sedangkan SAL dan SPL menjadi penciri pada sumbu utama PC-2 yang menjelaskan keragaman 15,46\% Karakter SAL dan SAK menjadi penciri pada sumbu utama PC-3 yang menjelaskan keragaman $14,13 \%$ dan LL dan SPK merupakan penciri pada sumbu utama PC-4 yang menjelaskan keragaman 11,07\%(Tabel4).

Distribusi individu-individu dari keempat populasi berdasarkan skor pada sumbu utama PC-1 dan PC-2 
Biplot (PC-1 \& PC-2: 40.55\%

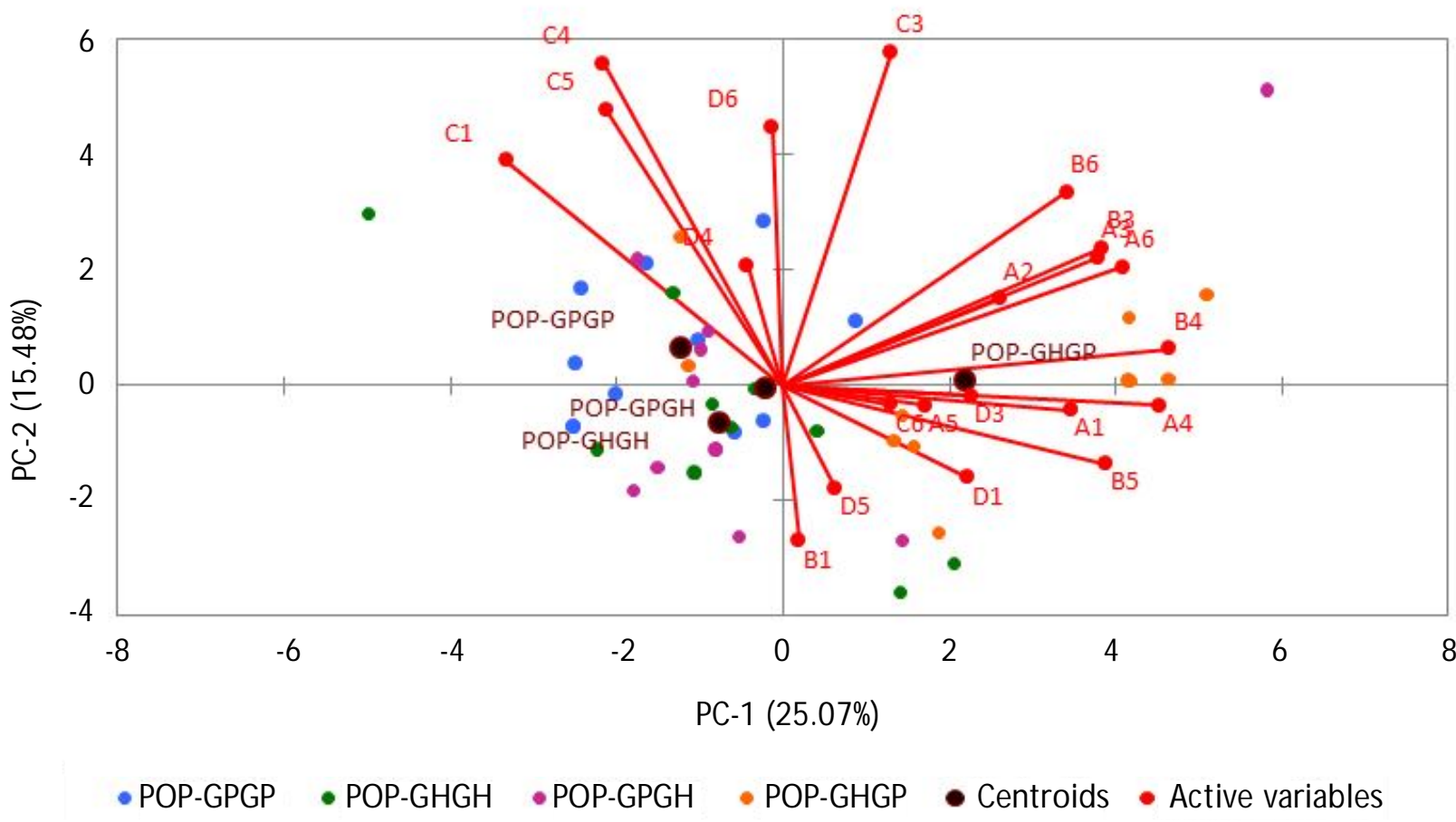

Gambar 1. Plot 21 karakter morfometrik dan skor individu-individu dari keempat populasi pada komponen utama PC-1 dan PC-2 (A1-D6: karakter truss).

Figure 1. The plot of 21 morphometric characters and individual scores from four populations onmain components of PC-1 and PC-2 (A1-D6: truss characters).

Biplot (PC-3 \& PC-4: 21.88\%)

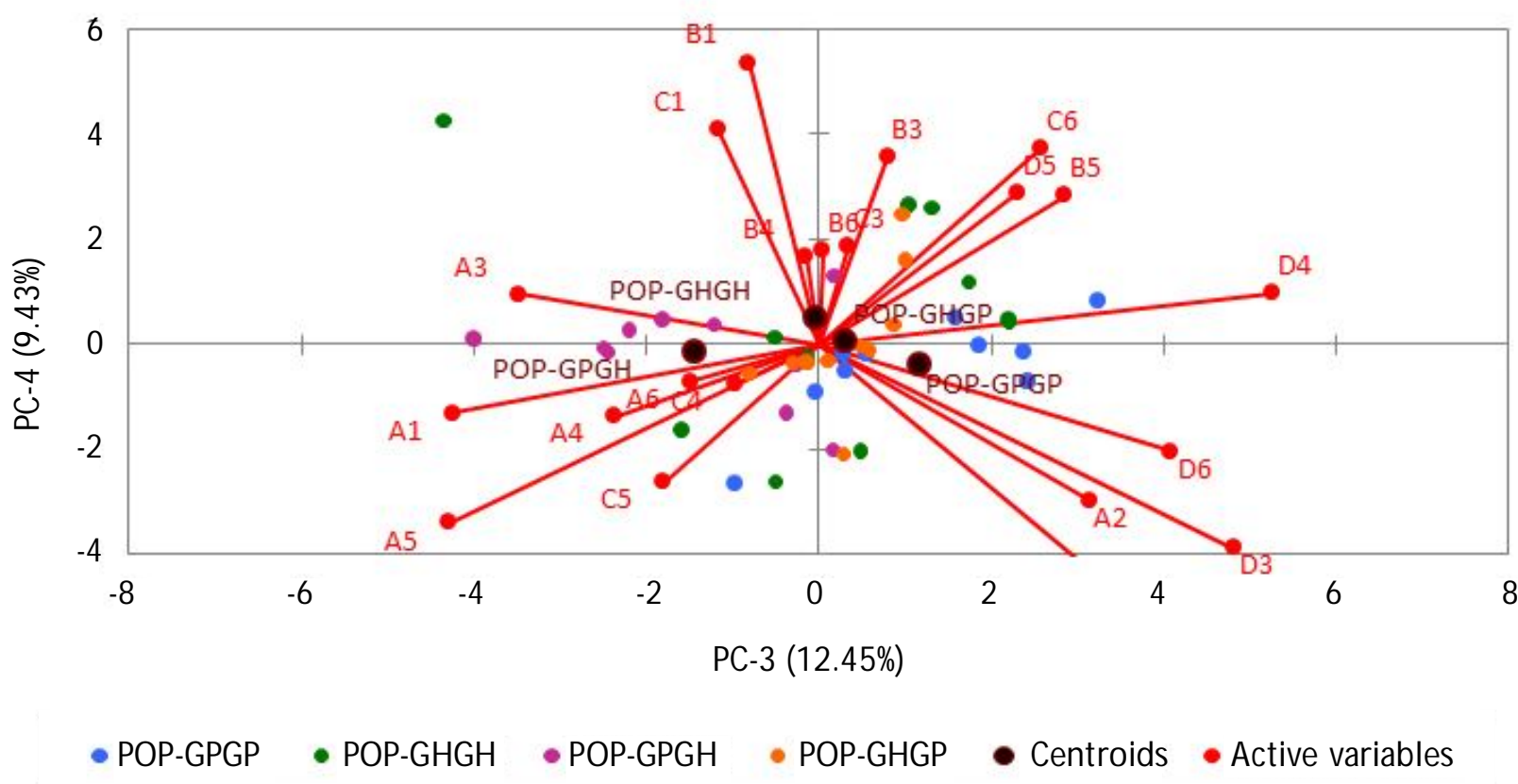

Gambar 2. Plot 21 karakter morfometrik dan skor individu-individu dari keempat populasi pada sumbu utama (PC-3) dan PC-4 (A1-D6: karakter truss).

Figure 2. The plot of 21 morphometric characters and individual scores from four populations onmain axis (PC-3) and PC-4 (A1-D6: truss characters). 
Tabel 4. Skor delapan karakter meristik, ragam, dan centroid keempat populasi pada empat sumbu utama

Table 4. The score of the eight meristic characters, variances, and centroids from the four populations on the four main axes

\begin{tabular}{lcccc}
\hline \multicolumn{1}{c}{ Karakter (Characters) } & PC-1 & PC-2 & PC-3 & PC-4 \\
\hline SPR & $\mathbf{0 . 7 2 9}$ & 0.074 & -0.157 & 0.198 \\
SDA & $\mathbf{0 . 7 2 3}$ & 0.135 & -0.368 & 0.135 \\
SEK & 0.594 & -0.144 & 0.27 & 0.275 \\
SAL & 0.032 & $\mathbf{0 . 6 7 4}$ & $\mathbf{0 . 4 7 9}$ & -0.311 \\
SPL & 0.405 & $\mathbf{0 . 6 4}$ & -0.189 & -0.018 \\
LL & -0.316 & 0.351 & 0.449 & $\mathbf{0 . 6 6 2}$ \\
SPK & 0.49 & -0.092 & 0.431 & $\mathbf{- 0 . 4 5 5}$ \\
SAK & 0.428 & -0.444 & $\mathbf{0 . 4 9 5}$ & 0.103 \\
Ragam yang dapat dijelaskan oleh komponen & & & & \\
Variance that can be explained by component & 2.095 & 1.237 & 1.130 & 0.886 \\
Persentase ragam yang dapat dijelaskan oleh komponen & & & & \\
Percentage of variance that can be explained by component & 26.185 & 15.463 & 14.127 & 11.071 \\
Persentase ragam kumulatif & & & & \\
Percentage of cumulative variance & 26.185 & 41.648 & 55.775 & 66.846 \\
\hline Centroid POP-GHGH & & & & \\
Centroid POP-GPGH & -1.027 & 0.043 & 0.411 & 0.506 \\
Centroid POP-GPGP & 0.27 & 0.196 & 0.221 & 0.013 \\
Centroid POP-GHGP & 0.277 & -0.215 & -0.138 & -0.236 \\
\hline
\end{tabular}

Keterangan: Nilai yang dicetak tebal merupakan karakter penciri pada sumbu utama, menunjukkan karakter dengan kontribusi signifikan

Note: $\quad$ The values in bold are the identifier characters on the main axis with significant contribution

disajikan pada Gambar 3, menunjukkan bahwa berdasarkan karakter SPR dan SDA yang menjadi penciri pada sumbu utama PC-1, populasi tetua (GH X $\mathrm{GH}$ ) berada pada bidang negatif. Hal ini cukup kontras bila dibandingkan dengan ketiga populasi lain yang berada pada bidang positif. Hal ini berarti populasi GH X GH memiliki jumlah SPL dan SDA yang lebih sedikit dibandingkan dengan GH X GP, GP X GH, dan GP X GP. Pada sumbu utama PC-2, posisi centroid keempat populasi berada dekat dengan titik tengah sumbu yang menunjukkan kedekatan antara satu populasi dengan populasi lainnya.

Pada sumbu utama PC-3 yang dicirikan oleh karakter SAL dan SAK, populasi GH X GH kontras dengan GH X GP, sementara GP X GP dan GP X GH meskipun berada pada bidang yang berbeda namun posisinya saling berdekatan dengan titik tengah sumbu PC-3. Pola yang hampir sama di mana GH X GH kontras dengan GH X GP terlihat pada sumbu utama PC-4 yang dicirikan oleh karakter LL dan SPK (Tabel 4 dan Gambar 4).

\section{Analisis Genotipe}

Pola pita elektroforesis yang diperoleh hasil visualisasi dari sebagian sampel yang dianalisis tertera pada Gambar 4. Polimorfisme dan heterozigositas populasi Galunggung Hitam dan Galunggung Putih tergolong rendah. Persilangan keduanya dapat meningkatkan nilai keragaman genetik yang dihasilkan (Tabel 5).

Analisis menggunakan AMOVA (Analysis Molecular Variance) menunjukkan bahwa tidak terdapat perbedaan yang nyata secara genetik antara persilangan ikan gurami yang diuji $(P>0,05)$ (Tabel 8). Ikan gurami pembentuk (GP X GP) mempunyai jarak genetik yang tinggi dengan $\mathrm{GH} X \mathrm{XH}$, sedangkan kedua persilangan yang dihasilkan mengikuti pola genetik induk betinanya. Populasi GP X GH mempunyai jarak yang dekat dengan GP X GP dan GH X GP mempunyai jarak genetik yang berdekatan dengan GH X GH (Tabel 7 dan Gambar 6). 
Biplot (PC-1 \& PC-2: 41.65\%

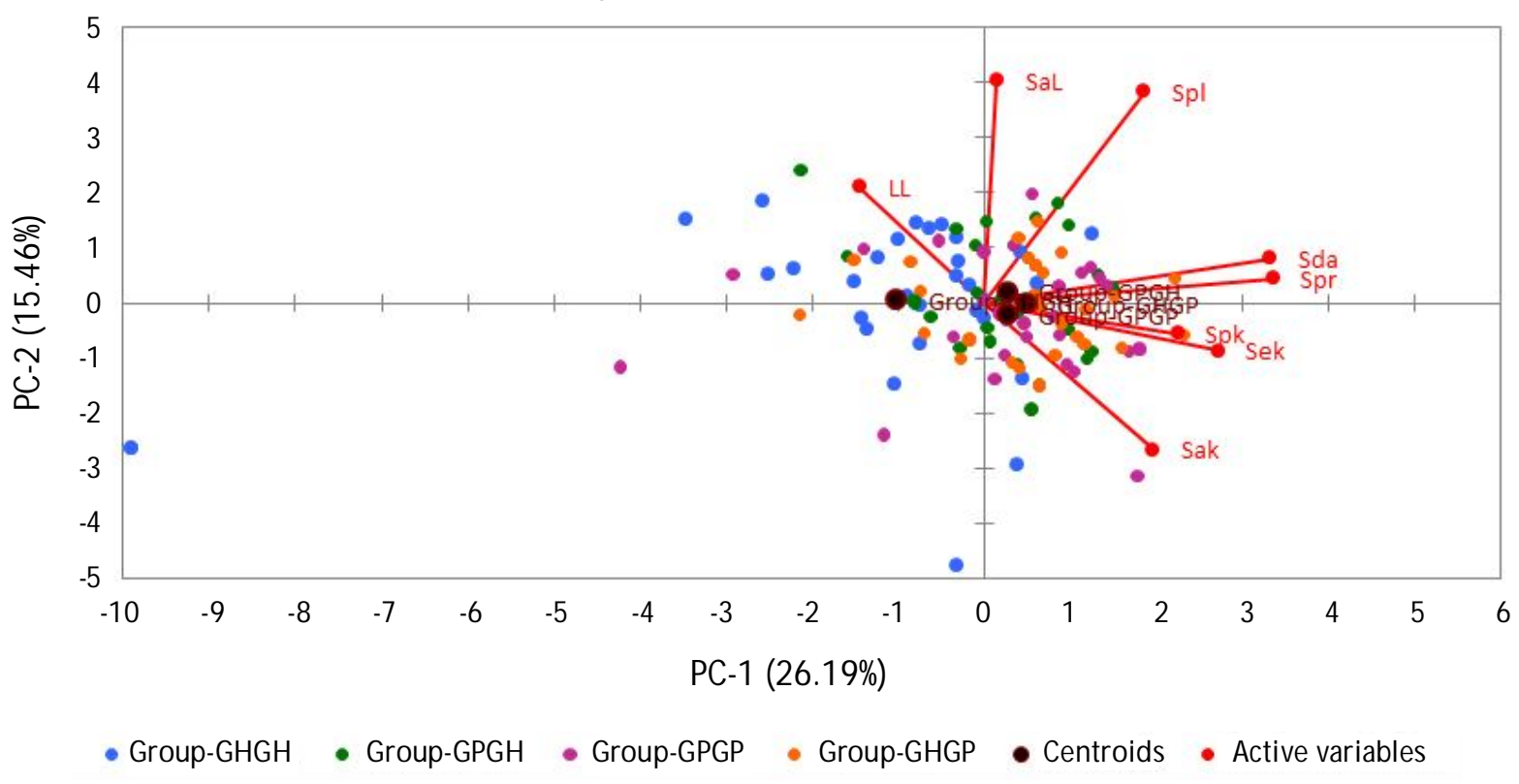

Gambar 3. Distribusi karakter meristik dan skor individu-individu dari populasi GP X GP, GPX GH, GH X GP, dan GH X GH pada sumbu utama PC-1 dan PC-2 (Spk: jari-jari keras sirip punggung, Spl: jari-jari lunak sirip punggung, Sda: jari-jari sirip dada, Spr: jari-jari sirip perut, Sal: jari-jari lunak sirip anal, Sak: jari-jari keras sirip anal, Sek: jari-jari sirip ekor, LL: linealateralis).

Figure 3. The distribution of meristic characters and individual scores from the populations of GP X GP, GPX GH,GH X GP, and GH X GH on the main axes of PC-1 and PC-2 (Spk: dorsal fin spiny rays, Spl: dorsal fin soft rays, Sda: pectoral fin rays, Spr: ventral fin rays, Sal: anal fin soft rays, Sak: anal fin spiny rays, Sek: caudal fin rays, LL: linealateralis).

\section{Biplot (PC-3 \& PC-24: 25.44\%)}

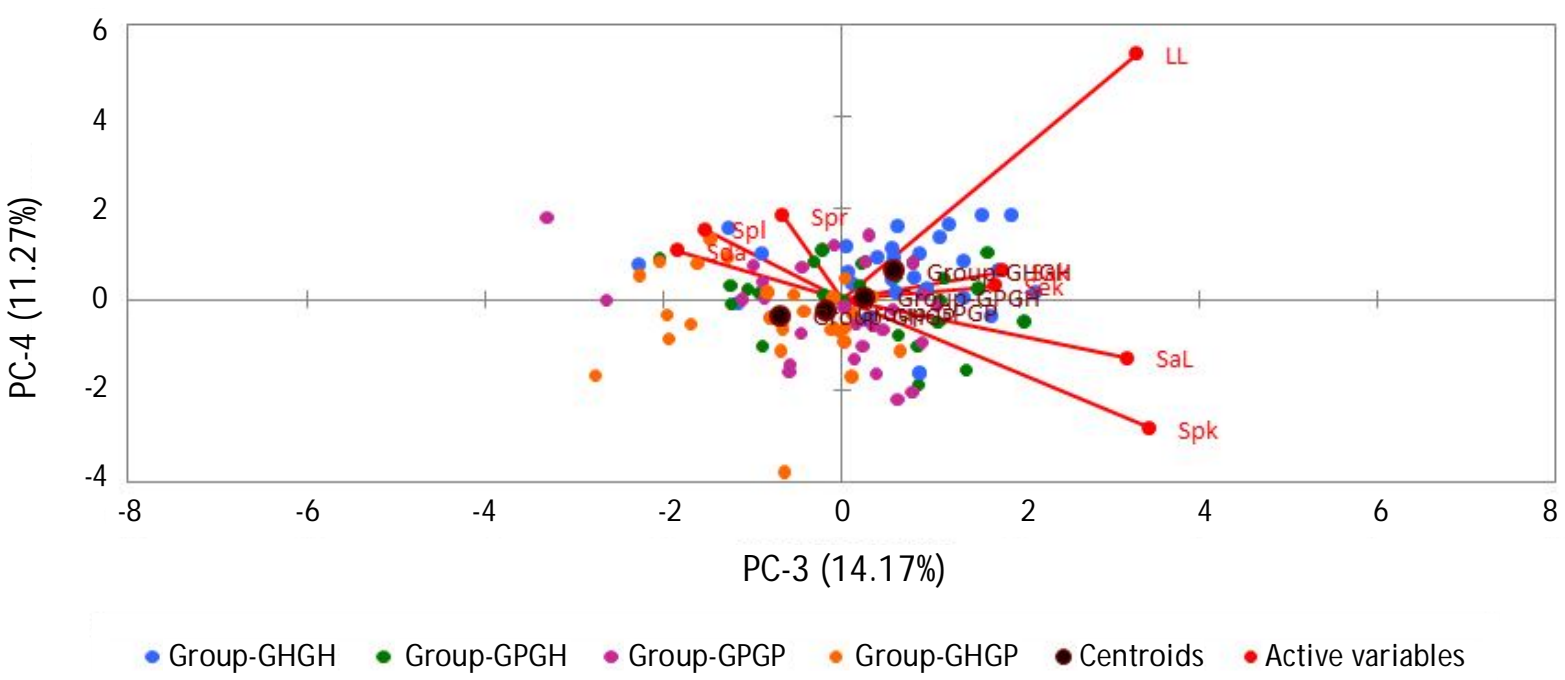

Gambar 4. Distribusi inidividu-individu dari populasi GP X GP, GP X GH, GH X GP, dan GH X GH, berdasarkan skor pada sumbu utama PC-1 dan PC-2 (Sda: jari-jari sirip dada, Spr: jari-jari sirip perut, Sal: jari-jari lunak sirip anal, Sak: jari-jari keras sirip anal, Sek: jari-jari sirip ekor, LL: linealateralis).

Figure 4. The distribution of individuals from the populations of GP X GP, GP X GH, GH X GP, and GH X GH based on scores from the main axes of PC-1 and PC-2 (Spk: dorsal fin spiny rays, Spl: dorsal fin soft rays, Sda: pectoral fin rays, Spr: ventral fin rays, Sal: anal fin soft rays, Sak: anal fin spiny rays, Sek: caudal fin rays, LL: linealateralis). 


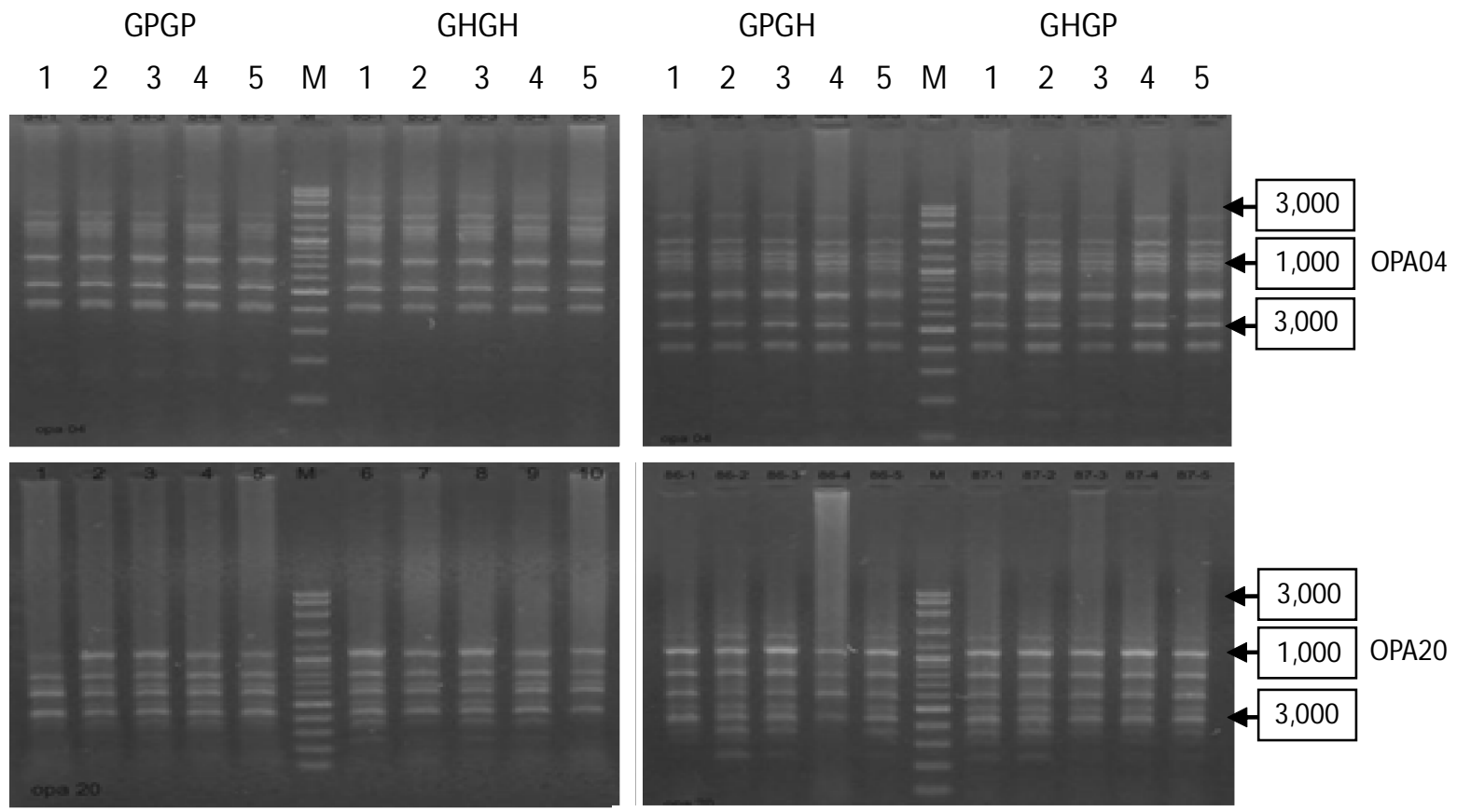

Gambar 5. Visualisasi elektroforesis hasil PCR-RAPD ikan gurami (M: marker, GP X GP: Galunggung Putih, GH X GH: Galunggung Hitam, persilangan GP X GH dan GH X GP).

Figure 5. Visualization of electrophoresis from PCR-RAPD on gouramy (M: marker, GP X GP: Galunggung White, GH X GH: Galunggung Black, hybrid of GP X GH and GH X GP).

Tabel 5. Nilai polimorfisme dan heterozigositas ikan gurami Galunggung Putih, Galunggung Hitam, dan persilangan dua arah keduanya

Table 5. Polymorphism and heterozygosity of gouramy strains (Galunggung White, and Galunggung Black) and their hybrids

\begin{tabular}{lcccc}
\hline \multirow{2}{*}{$\begin{array}{c}\text { Parameter } \\
\text { Parameters }\end{array}$} & GP X GP & GP X GH & GH X GP & GH X GH \\
\cline { 2 - 5 } & 0.0485 & 0.0984 & 0.1688 & 0.0676 \\
\hline $\begin{array}{l}\text { Heterozigositas } \\
\text { Heterozygosity }\end{array}$ & 9.0909 & 18.1818 & 31.8182 & 13.6364 \\
$\begin{array}{l}\text { Polimorfisme } \\
\text { Polymorphism (\%) }\end{array}$ & & & & \\
\hline
\end{tabular}

Tabel 6. Nilai P dari empat populasi ikan gurami Galunggung Putih, Galunggung Hitam, dan persilangan dua arah keduanya

Table 6. $\quad \mathrm{P}$ values of four populations of gouramy strains (Galunggung White and Galunggung Black) and their hybrids

\begin{tabular}{ccccc}
\hline Populasi (Populations) & GP X GP & GP X GH & GH X GP & GH X GH \\
\hline GP X GP & $* * * 4 * *$ & & & \\
GP X GH & 1.0000 & $* * * * * *$ & & \\
GH X GP & $0.6523^{\mathrm{NS}}$ & $0.6252^{\mathrm{NS}}$ & $* * 4 * * *$ & \\
GH X GH & $0.4561^{\mathrm{NS}}$ & $0.4512^{\mathrm{NS}}$ & 1.0000 & $* * 4 * 4 *$ \\
\hline
\end{tabular}

NS $=$ Tidak berbeda nyata $p a d a$ taraf $P>0,05$

NS $=$ No significant difference in the level of $P>0.05$ ) 
Ikan gurami Galunggung Putih dan Galunggung Hitam memiliki nilai keragaman genetik dalam bentuk nilai heterozigositas yang cukup rendah, persilangan keduanya menghasilkan nilai keragaman genetik yang meningkat. Heterozigositas merupakan ukuran keragaman genetik berdasarkan proporsi jumlah individu heterozigot dalam populasi (Soewardi, 2007). Penurunan tingkat keragaman genetik erat kaitannya dengan menurunnya heterozigositas gen. Nugroho et al. (2016) mengemukakan bahwa rendahnya keragaman genetik merupakan gambaran umum yang ditemui pada jenis ikan air tawar sebagai akibat keterbatasan migrasi secara alami, isolasi populasi dan genetic drift (Soewardi, 2007).

Nugroho et al. (2011) yang menguji keragaman genetik menggunakan metode RAPD menunjukkan hasil persilangan antara Paris-Bastar mempunyai nilai heterozigositas 0,2721; sedangkan persilangan antara Blusafir-Paris sebesar 0,1116. Nugroho \& Kusmini (2007) menyatakan bahwa ikan gurami populasi Batanghari (Jambi) mempunyai variasi genetik yang lebih tinggi dibandingkan ras Bluesafir, Paris, dan Bastar. Arifin et al. (2007) memperoleh nilai keragaman genetik yang tinggi pada empat populasi ikan nila dengan rata-rata nilai heterozigositas 0,2146 dan polimorfisme $56,62 \%$ Gustiano et al. (2011) yang menguji keragaman genetik pada hasil persilangan tiga populasi ikan nila, mendapatkan nilai heterozigositas cukup rendah berkisar antara 0,04-0,12 dengan nilai polimorfisme berkisar antara $10,46 \% 27,93 \%$ Nilai heterozigositas pada ikan kelabau (Osteochilus kelabau) berkisar antara 0,0100-0,1651 (Kusmini et al., 2011), pada ikan semah (Tor sorro) berkisar antara 0,09090,1407 (Asih et al., 2008).

Ikan gurami Galunggung Hitam dan Galunggung Putih, serta persilangan dua arah keduanya menunjukkan tidak berbeda nyata secara genotipe $(P>0,05)$ berdasarkan nilai Fst. Pada penelitian menggunakan metode isozyme, diperoleh hasil bahwa ikan gurami strain Bastar, Bule, dan Bluesafir merupakan populasi yang tidak berbeda dan persilangan ketiganya juga menunjukkan nilai yang tidak berbeda nyata (Nugroho \& Kusmini, 2007). Nugroho et al. (2016) mendapatkan sebagian besar hasil tidak terdapat perbedaan yang nyata secara genetik antara strain ikan kalui (gurami) yang diuji $(P>0,05)$ pada strain Tambago, Palapah, Jepun, dan Krista, sedangkan untuk strain Merah berbeda nyata $(P<0,05)$.

Hibridisasi antara induk ikan gurami Galunggung Hitam dengan Galunggung Putih menghasilkan ikan gurami dengan keragaan karakter yang bervariasi antara satu dengan yang lainnya. Hibridisasi yang dilakukan menghasilkan variasi morfologis baru dengan variasi genetik yang meningkat. Peningkatan variasi genetik yang terjadi sangat berguna dalam menekan laju inbreeding dan berperan dalam peningkatan produktivitas budidaya.

\section{KESIMPULAN}

Hibridisasi populasi gurami Galunggung Hitam dan Galunggung Putih menghasilkan populasi hibrida dengan beberapa variasi morfologis yang baru. Berdasarkan karakter morfometrik dan meristik, profil hibrida GH X GP dan GP X GH bervariasi sesuai dengan kombinasi hibrida dan karakter yang diamati. Pada kombinasi hibrida tertentu beberapa karakter morfometrik dan meristik bersifat heterosis positif, heterosis negatif atau bersifat intermediate. Nilai polimorfisme dan heterozigositas populasi tetua adalah rendah, persilangan keduanya meningkatkan nilai keragaman genetik yang dihasilkan. Hibridisasi yang dilakukan menghasilkan variasi morfologis baru, dengan variasi genetik yang meningkat.

\section{UCAPAN TERIMA KASIH}

Ucapan terima kasih kepada Ir. H. Djafar Ismail, M.M. Kepala Dinas Kelautan dan Perikanan Provinsi Jawa Barat dan seluruh teknisi ikan gurami dan staf BPBIGN Singaparna. Kegiatan ini didanai DIPA BPBIGN Singaparna, Dinas Kelautan dan Perikanan Provinsi Jawa Barat.

\section{DAFTAR ACUAN}

Arifin, O.Z., Nugroho, E., \& Gustiano, R. (2007). Keragaman genetik populasi ikan nila (Oreochromis niloticus) dalam program seleksi berdasarkan RAPD. Berita Biologi, 8(6), 465-471.

Arifin, O.Z., Subagja, J., \& Hadie, W. (2015). Karakteristik biometrik tiga populasi ikan semah (Tor douronensis, Valenciennes, 1842) dalam mendukung konservasi sumberdaya genetik. Jurnal Ikhtiologi Indonesia, 15(2), 143-154.

Ariyanto, D. \& Imron. (2008). Analisis keragaman morfometrik dan genetik pada strain ikan mas (Cyprinus carpio). Jurnal Perikanan, 10(1), 53-63.

Asih, S., Nugroho, E., Kristanto, A.H., \& Mulyasari. (2008). Penentuan variasi genetik ikan batak (Tor sorro) dari Sumatera Utara dan Jawa Barat dengan metode RAPD. J. Ris. Akuakultur, 3(1), 91-97.

Brzesky, V.J. \& Doyle, R.W. (1988). A morphometrics criterion for sex discrimination in tilapia. The Second International Symposium on Tilapia in Aquaculture. Bangkok Thailand, ICLARM Conference Proceeding, 15, 439-444.

Gustiano, R., Soelistyowati, D., Fauzan, A.L., \& Arifin, O.Z. (2011). Keragaman genetik hibrida beberapa 
strain ikan nila (Oreochromis niloticus Bleeker). Berita Biologi, 10(6), 819-825.

Kusmini, I.I., Gustiano, R., \& Mulyasari. (2011). Karakterisasi genetik ikan kelabau (Osteochilus kelabau) dari berbagai lokasi di Kalimantan Barat mengunakan metode RAPD (Random Amplified Polymorphism DNA). Berita Biologi, 10(4), 449-454.

Langer, S., Tripathi, N.K., \& Khajuria, B. (2013). Morphometric and meristic study of Golden Mahseer (Tor putitora) from Jhajjar Stream India. Journal of Animal, Veterinary and Fishery Sciences, 1(7), 1-4.

Miller, M.P. (1997). Tools for population genetic analysis (TFPGA) version 1.3. Department of Biological Science. Northern Arizona University, Arizona, USA.

Nei, M. \& Tajima, F. (1981). DNA polymorphism detectable by resctriction endonuclease. Genetics, 97 , 146-163.

Nugroho, E., Azrita, Syandri, H., \& Refilza. (2016). Evaluasi keragaman genetik ikan kalui (Osphronemus goramy) dari Kabupaten Lima Puluh Kota, Sumatera Barat berdasarkan marka random amplified polymorphism DNA (RAPD). J. Ris. Akuakultur, 11(4), 313-319.

Nugroho, E. \& Kusmini, I.I. (2007). Evaluasi variasi genetik tiga ras ikan gurame (Osphronemus gouramy) dengan metode isozyme. J. Ris. Akuakultur, 2(1), 51-57.

Nugroho, E., Nafiqoh, N., \& Gustiano, R. (2012). Produktivitas beberapa varietas ikan gurame (Osphronemus gouramy). Prosiding Forum Inovasi Teknologi Aquakultur, hlm. 1095-1101.

Nugroho, E., Sundari, S., \& Jatnika. (2011). Variasi genetik hibrida ikan gurame dianalisis dengan menggunakan marker RAPD. J. Ris. Akuakultur, 6(1), 1-6.

Radona, D. \& Nafiqoh, N. (2014). Karakterisasi reproduksi dan nilai heterosis hasil persilangan ikan gurame bastar dan bluesafir. Berita Biologi, 13(2), 153-159.

Rahardjo, M.F., Sjafei, D.S., Affandi, R., \& Sulistiono. (2010). Ichtyologi. Bandung: CV Lubuk Agung, 395 hlm.

Rogers, J.S. (1972). Measures of genetic similarity and genetic distance. In Studies in genetics VII. University of Texas Publication, 7213, 145-154

Sheridan, A.K. (1981). Crossbreeding and heterosis. Animal Breeding Abstracts, 49, 131-144.

Saanin, H. (1984). Taksonomi dan kunci identifikasi ikan II. Bandung: Binacipta, $245 \mathrm{hlm}$.

Setijaningsih, L., Arifin, O.Z., \& Gustiano, R. (2007). Karakterisasi tiga strain ikan gurame (Osphronemus gouramy Lac.) berdasarkan metode truss morfometriks. Jurnal Iktiologi Indonesia, 7(1), 2330.

Soewardi, K. (2007). Pengelolaan keragaman genetik sumber daya perikanan dan kelautan. Departemen Manajemen Sumberdaya Perairan, Fakultas Perikanan dan Ilmu Kelautan, Institut Pertanian Bogor. Bogor hlm. 153.

Sularto, Febrianti, R., \& Suharyanto. (2016). Estimasi heritabilitas dan respons seleksi persilangan ikan gurami (Osphronemus goramy Lac.). J. Ris. Akuakultur, 11(1), 2016, 23-28.

Tave, D. (1999). Inbreeding and brood stock management. FAO Fish Technical Paper. No. 392, FAO. Rome. p. 122. 